\title{
Community Stories and Growth Through Research-Based Theatre
}

\author{
Christopher Cook and George Belliveau
}

\begin{abstract}
Community members and staff at the University of British Columbia (UBC) Learning Exchange collectively created a theatre piece, based on stories from Vancouver's Downtown Eastside (DTES), entitled Voices UP! This article examines the impact this project had on four DTES community members who took part in the collective creation process. The results are presented as both a thematic analysis and a short play script, entitled Give Me Your Hands. Give Me Your Hands is a play about making a play, illustrating the shared and individual learning experiences of those who took part in a communitybased collaborative theatre process.
\end{abstract}

\section{Background}

As an embodied storytelling practice, theatre has the potential to contribute to learning and well-being in community contexts. The therapeutic relevance of theatre has been posited for centuries-in Ancient Greece, Aristotle argued drama was a means of processing emotion (Aristotle, 1970). More recently, the well-being benefits of art creation have been advocated by authors in psychology and health-related fields (Leckey, 2011; Lomas, 2016; Stuckey \& Nobel, 2010), education (Gildin et al., 2013; Mitchell \& Ezcurra, 2017), as well as in arts-based literature (Boydell et al., 2016; Cox, Brett-MacLean, $\&$ Courneya, 2016). How and why the arts may bring therapeutic benefits to learning spaces is worthy of further investigation; in particular for arts educators, researchers, and practitioners, whose central goal is to make a positive difference in the lives of the communities with whom they collaborate.

In 2016, staff members at the University of British Columbia (UBC) Learning Exchange began to work on a theatre piece with community members in Vancouver's Downtown Eastside (DTES), a community whose notorious reputation for drug use, poverty, mental illness, homelessness, and crime often overshadows the strengths of its residents. Over the next two years, more than 30 community members, artists, and staff would collectively write, rehearse, and present the play, entitled Voices UP!, four times. Voices UP! consists of a collection of dramatized stories shared by, and about, community members' experiences at the Learning Exchange. This article examines the impact this project had on four of the community members who took part in the collective creation process. To represent some of the insights of the analysis, we include scenes from Give Me Your Hands, a play created from interviews with the four community members. As a meta-research-based play, Give Me Your Hands helps to better represent the shared and individual experiences of learning and positive growth from those who took part in Voices UP! 
The UBC Learning Exchange was established in 1999, and it brings together members of the community and university to collaboratively engage in knowledge sharing, offering inclusive and accessible educational opportunities. Based in the DTES, in Vancouver's Chinatown, the Learning Exchange serves a diverse range of community members. Individuals living and/or accessing programs in the DTES may face multiple barriers, including living below the poverty line, unemployment, and mental wellness challenges. The DTES is home to a large population of seniors, and the DTES neighborhood of Chinatown includes large immigrant populations. The city has recognized the need to promote sustainable arts and culture initiatives to support individual and community health (City of Vancouver, 2014), and the Learning Exchange has launched a range of low-barrier, arts-centered programing, such as Voices UP!, to address the diverse needs of the community members it serves.

O'Connor and O'Toole (2017) suggest that arts-based practitioners should generate artistic initiatives that create "space for people to reflect on who and how they are in the world and, just as importantly, who they might become" (p. 63). Collective creation has previously been utilized in a number of contexts where well-being through theatre-making was central to the project (Prendergast \& Belliveau, 2018; Sadeghi-Yekta, 2017; Wager, 2014). In a review of studies on the creative arts and their contribution to mental health, Leckey (2011) concludes that research evidence points to the potential for arts to positively affect well-being in a variety of ways, including self-esteem, mood, relaxation abilities, and optimism. Psychologists and counsellors often borrow elements of theatre-enactment of stories, improvisation, and spontaneous play-as tools for use in the therapy room (Snow, D'Amico, \& Tanguay, 2003). Replacing the counselling room with a community-based learning space, this article aims to show how participants stories of taking part in Voices UP! built on the authors' understanding of collective theatre and storytelling to include therapeutic benefits.

\section{Research Approach}

\section{Participants and Data Collection}

Four community members agreed to take part in the study. ${ }^{1}$ Three participants identified as seniors, and two identified as Chinese Canadian, one as Canadian, and one as Indigenous. Three identified as male, and one as a female. The study drew participant stories from several data sources, though the three we'll explore more closely in this article include the individual interview transcripts, participant sketches done during interviews, and objects chosen by the participants to represent their collective creation experiences. Each participant took part in an individual narrative interview of approximately 60 minutes. The interviews began with a request that they share stories around their experiences of Voices UP!, and portions of the interviews were audio recorded. Participants were invited to bring an object to the interview, such as a prop they made for the show, a personal item, or a found object, and had the option of sketching their experience. Participants had the opportunity to speak about this object and their sketches as part of the interview. Chris, lead author of this article, conducted the interviews, and was part of the entire development process of Voices UP! 


\section{Data Analysis}

All audio recordings from the interviews were transcribed, and the four participants were invited to make any changes they wished to the transcript. An analysis of the narratives present in the interviews was done following Braun and Clarke (2006), who describe thematic analysis as a means of "identifying" and "reporting patterns (themes) within data" (p. 79). Combining the analysis of the transcripts, sketches, and chosen objects, a series of monologues and scenes were produced. Collectively, with the participants, these were interwoven into Give Me Your Hands, a short script generated from immersion in the research data, and an analysis created with the aesthetic sensibilities of a playwright as researcher (Belliveau, 2007; Mackenzie \& Belliveau, 2011). As Leavy (2009) writes, "artistic practice" and qualitative practice are both "crafts" (p. 10)—effective qualitative research requires the transposition of data into a new form that offers insight, just as theatre and other art forms may encourage new connections among diverse perspectives.

\section{Findings}

A thematic analysis of the interview transcripts and chosen objects led to the establishment of six core themes, of which four are discussed below. The theme titles are in vivo quotes from interview transcripts. Excerpts from Give Me Your Hands accompany the thematic analyses, artistically opening up insights and creatively highlighting findings gleaned from the study. Script selections have been edited for clarity and length to facilitate their inclusion in this article. Puppets were central to many of the experiences reported by participants in this study and are the fictional characters that populate Give Me Your Hands.

\section{Give Me Your Hands: A Research-Based Play About Collective Playmaking}

\section{Cast of Characters}

ZHAN: $\quad$ A sock puppet. A creator/performer of Voices UP! The actor playing ZHAN should be older.

EHREN: $\quad$ A sock puppet. A creator/performer of Voices UP! The actor playing EHREN should be younger. This actor also runs the projections during the show.

SHELLEY: $\quad$ A sock puppet. A creator/performer of Voices UP! The actor playing SHELLEY should be older.

\section{Setting}

The play takes place in a room at the Learning Exchange-a sometimes classroom, sometimes meeting room, sometimes art-studio, sometimes karaoke club, and one of the primary rehearsal spaces for Voices UP! 


\section{Give Me Your Hands Excerpt 1: First Showtimers}

\begin{tabular}{|c|c|}
\hline EHREN & (to audience) Over 22 months, we made a play together. \\
\hline ZHAN & (to audience) Me, this is my first time to do a show. \\
\hline EHREN & $\begin{array}{l}\text { These words are directly quoted from or } \\
\text { inspired by interviews I did } \\
\text { with community members who took part } \\
\text { in the creation and performance of Voices UP! }\end{array}$ \\
\hline SHELLEY & (to audience) We're talking about making a script- \\
\hline ZHAN & $\begin{array}{l}\text { (shaking arms, covering mouth) } \\
\text { Bit nervous. It's just about- } \\
\text { "Will we be successful?" } \\
\text { "Will we?" } \\
\text { "Can we do it?" }\end{array}$ \\
\hline EHREN & $\begin{array}{l}\text { I'm a first-timer-not to theatre, but to academia. } \\
\text { How do you write a play and make it research? }\end{array}$ \\
\hline SHELLEY & $\begin{array}{l}\text { To be honest, I have no idea what's going to happen. } \\
\text { Just blank! }\end{array}$ \\
\hline
\end{tabular}

Theme one: "I learned something—how to do a play." "It's a fun activity," said a participant, referring to the process of creating Voices UP! Beyond pure enjoyment, participants pointed to Voices UP! as a skill-building experience. In putting on a theatre production, the collective explored acting and scriptwriting, song writing and performance, set design, prop design, staging and direction, as well as postshow talk-backs with the audience. Skill development is an important insight, as it offered agency to the participants and transferable learning they could take away from being a part of the collective creation process.

In terms of performing in Voices UP!, some participants described the thought of being in front of an audience as provoking anxiety, while others expressed feeling at ease with public speaking from the beginning. For one community member who did feel nervous, practicing helped: "After a few times [in] rehearsal, you feel more comfortable." Similarly, another participant stated that the rehearsal period gave "each person the chance to speak in public" before the performances. Both participants implied rehearsal was a means of laddering up to performance, working from speaking in front of other members of Voices UP! towards acting in front of a general audience. 
Voices UP! was presented as a staged reading, meaning that the cast performed with scripts in hand, and memorization was not required. Despite reading from the script during the performance, one participant described using the acting skill of "expression" to convey meaning:

I don't want to, hopefully, be just reading out a sermon on the stage. The expressions, the intonation, and the volume of it, has a lot to do with the show ... in attracting people's attention ... You've got to bring [the audience], and you've got to guide them through. Because you are trying to tell [them], "This is what I am going to say."

Most theatre creation processes work towards a performance of some kind, and each participant described how the performances became a goal. One collective member said "everyone" was working hard, putting in "energy" and "effort" until "the show." Two participants asked when the next performance of Voices UP! would be during their research interviews, and one provided the name of a venue for a future show. These insights suggest how all four participants embraced working towards performance as an overarching goal of making a play, alongside gaining broader skills in theatre-making over the nearly two years that Voices UP! was being developed.

\section{Give Me Your Hands Excerpt 2: VOICES UP?}

EHREN (to audience) We help each other make the script-

SHELLEY I still don't really think

we have any idea what we're doing.

ZHAN Every time when we were meeting, we discuss the story, the lines, the characters. Everybody gives ideas and sentences. Ehren writes it down.

EHREN People have different opinions, different ways of saying things.

And of course, we try to work through it.

SHELLEY You've got to listen-

it's just a matter of sharing different ideas

to make the whole thing better.

Actually, Voices UP!-

it's a very good title for our show.

We really can voice up our opinions and everything.

ZHAN No problem with most people in the group.

Sometimes someone is hard to handle,

But what can I do? Just-

I try to keep my feelings to myself,

try to keep my voice down. 


$\begin{array}{ll}\text { EHREN } & \text { (to ZHAN) But it's called Voices UP! } \\ \text { ZHAN } & \text { (to EHREN) In case someone blows up or something. } \\ \text { (to audience) I try to keep it to myself. } \\ \text { SHELLEY }\end{array}$

Theme two: "The creation of relationship." Theme two illuminates the Voices UP! creation and performance process as a means of cultivating and developing relationships, both within and outside of the collective. This theme was present in all four transcripts. One participant described the collective as a "family" during her interview:

We were very happy because we looked like a big family. For example, if I say, "Oh! Today I want to change how the puppet is looking," then somebody can give me an idea ... The group ... help[ed] each other.

The above quotation implies a connection between the relationships that developed and supporting one another in the process of creating the show. As suggested by offering an image of a family, the participant also implied a feeling of belonging. Summarizing the experience of making a play overall, she said, "we have membership," the collective is "all together." 
A sense of belonging was echoed by another participant, who said, "I want[ed] to be part of" the collective. Additionally, this participant highlighted the interactions between audience and cast during Voices UP! performances, saying "this is also a relationship": "They share in our ideas, thinking, expressions, when we are on stage-and we look at them, and we get feelings from them too. It's both ways. It's always the word 'interact.' And it's also the word 'relationship.'"

The relationship between performers and audience members was also present in participants' descriptions of the post-show talk-backs:

I like to be with the audience. I like to listen to them. Because they are from a different group, not from the Learning Exchange ... They would have asked me a question ... from their own point of view, which is something I would never experience.

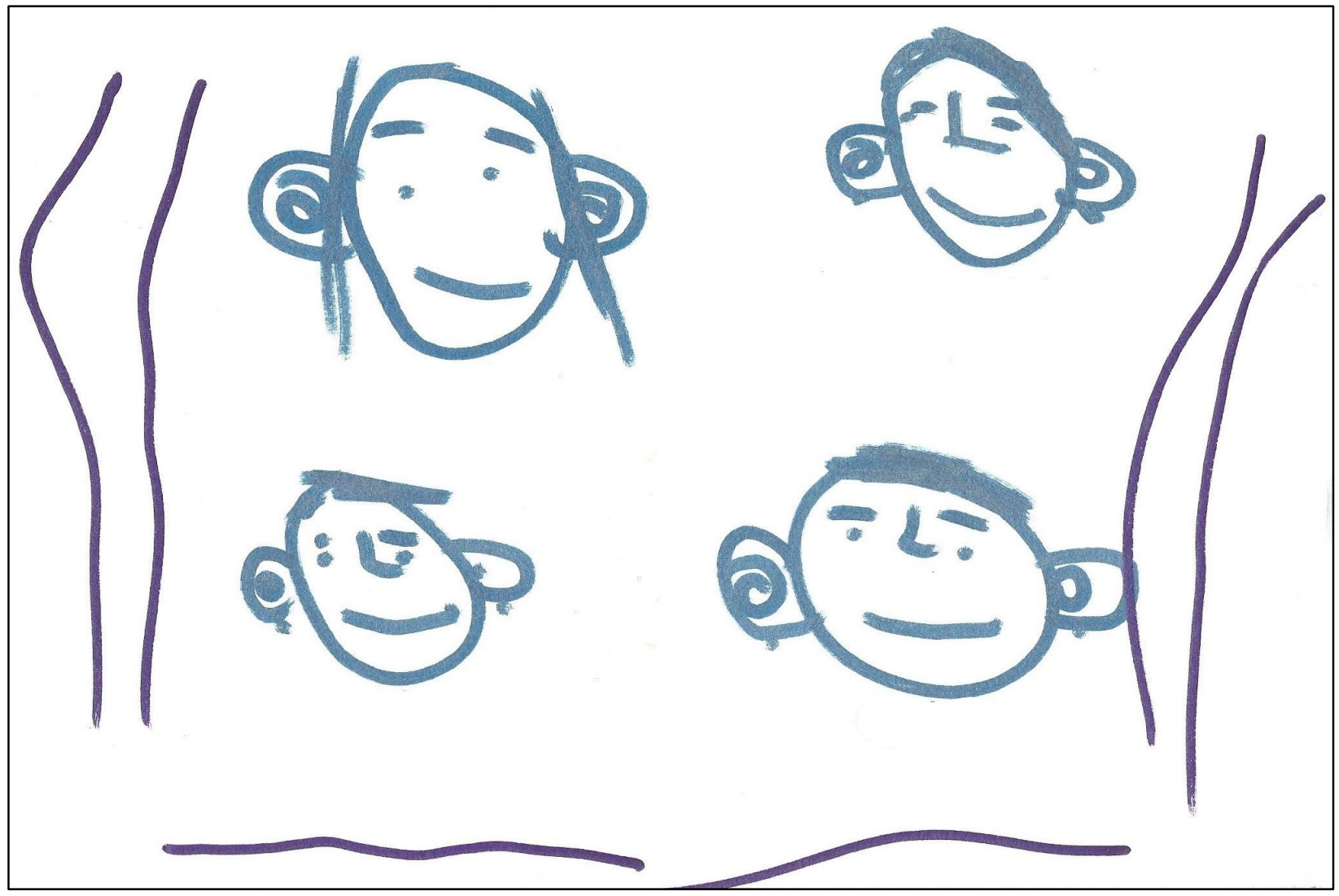

Fig. 1: Drawing by participant

Another participant drew the above sketch during his interview to represent his experience of Voices UP! - "friends" onstage, during performances (see Figure 1). The few dark vertical lines representing the curtain, and solitary horizontal line representing the stage, are only a backdrop to the lighter, smiling faces of the cast that take up most of the page. The open faces draw our focus as we view the sketch. 
Interestingly, although the participant described the faces as "friends" with each other, they are smiling at us - the viewers — extending the relationship outside of the Voices UP! group.

\section{Give Me Your Hands Excerpt 3: A Puppet Is Born}

EHREN turns to ZHAN and SHELLEY.

EHREN Hey, Shelley, Zhan—we're making sock puppets!

ZHAN (to EHREN) Oh really?

SHELLEY (to EHREN) Well, I don't know anything about it ...

ZHAN (to EHREN) So nice!

SHELLEY (to EHREN) I'm willing to give it a try.

(to audience, quietly_an aside) Socks!?

ZHAN (to audience, quietly-an aside) No clue what we'll have at the end.

EHREN Doesn't matter what kind of puppet you want to make. Here-

EHREN cycles through projections of various materials for making sock puppets, like the material the audience has used to create their own puppets.

ZHAN (to audience) All the different items, different materials(playful, having fun, to SHELLEY) "Hey! I want bigger puppet eyes!"

SHELLEY (to ZHAN) "I want my eyes lower!" (to audience) I never knew for socks, other than putting on your feet, you can work it into something else! I had no idea that it would end up into something very much different than just a sock, a piece of sock.

ZHAN We each make our own, But the group is making all these puppets together. When we finish, we give them names.

EHREN cycles through photos of the sock puppets from Voices UP!

EHREN I love the one named "SUPER SKY"!

SHELLEY I don't want to name mine "John" or "Mary" then it just comes up in my mind: the word "Love."

That's what I really want to show. 
I go home that night, I find my teddy bear-

it's wearing a little sweater with

"LOVE" embroidered on it.

So I put it on my puppet.

$\begin{array}{ll}\text { ZHAN } & \begin{array}{l}\text { Almost like people } \\ \text { when they have babies- } \\ \text { they give them names too. }\end{array} \\ \text { SHELLEY } & \begin{array}{l}\text { "Love" is not just a name. } \\ \text { There's a lot of feelings, } \\ \text { a lot of meanings at the back of that name. }\end{array} \\ \text { ZHAN } & \begin{array}{l}\text { It looks like- } \\ \text { the puppets- } \\ \text { it looks like they're born. }\end{array}\end{array}$

Theme Three: "A puppet can be like a little bridge." After the first few months of developing and rehearsing Voices UP!, a member of the collective suggested the group create a scene with puppets. The collective did not have time to develop the scene prior to their first and second performances, but in the fall of 2016, the group created sock puppets and added them to the script. The collective performed the show twice with the puppets, who became significant characters, with their own dedicated scenes.

Linked to the theme of relationships, the third theme describes puppetry as a communication tool. It highlights how puppetry became a major component for many of the participants' descriptions of Voices UP!: "And I find it interesting ... I never imagined that a puppet can be like a little bridge. We are building a bridge. For both sides. Me. And the other people. A bridge for the other group members."

During their interview, the participant quoted above posed the question, "How do you interact with other people?" He answered by describing the puppets as "a method of communication."

In a similar vein, a participant explained that the puppets were a tool to "make friends," because they could "use the puppet to talk to each other." The participant spoke of the puppets-rather than the collective members-writing, rehearsing, and performing the play. For example, he said, "all the puppets [developed] the Voices UP! script, the whole group of puppets [practiced], and the puppets gave a successful performance." The participant implied that the puppets were characters that collective members could step into when onstage, during performances, and offstage as well: "Every time when we are practicing, if one of the puppets doesn't like [an] idea [in the script], they can change it right away." In other words, the puppets may have offered a means of voicing opinions safely: a collective member was not wanting to change the script-his puppet was.

The puppet characters may also have offered confidence and a tool of overcoming anxiety during the performance, giving the group something to focus on: 
It feels like we were real puppets. We're not people-[You] are not [you], [I] am not [me]—we are into the puppet. We are the puppets. In the show, everybody is not thinking of themselves, they are thinking of the group of puppets. I don't know - I don't know if that [was] the idea or not, but that's my feeling.

\section{Give Me Your Hands Excerpt 4: Shelley's Solo}

SHELLEY comes back on stage, and ZHAN and EHREN take seats in the audience.

SHELLEY "I am a puppet. My name is Love."

Next person says,

"My name is John, I am also a puppet."

But I wanted to sound more interesting.

I added, "I was born at the Learning Exchange."

Then, "I'm a Canadian."

We are all Canadians, we are all part of it.

That's what I wanted to tell the audience.

It's not that I wish to take up a couple of seconds on air,

but to enhance-

I hope the puppet's name, Love,

can draw people's attention.

Because if you just say,

"I am John," they will forget after half a minute.

How did I come up with that name?

Well-Love is not just a name.

There's a story behind it.

First, as we were half-way through the process-

I lost somebody.

I lost him.

He is gone forever.

So much in grief, so much in Love.

I lost my Love.

In every way,

In every sense the word means-

Love is a big word.

Then the second part is:

I want to emphasize Love.

We all need Love.

You can love anything —anything!

Your tea,

You can love your pet,

your work.

You can love a certain person.

Love makes a happier life, a better world.

A famous English poet once said: 
EHREN and ZHAN stand and speak from the audience.

EHREN "The best portion of a good puppet's life:

ZHAN "Their little nameless unremembered acts of kindness-

SHELLEY "And Love."

Theme four: "I want to be creative." Voices UP! offered opportunities for both expressive arts, such as performance, and visual arts, such as set design. This theme acknowledges the desire and possibility for collaborative and individual creative expression present in the participants' experiences of collectively creating a play. "I don't want to miss any part of it," said one participant, who tried to be present throughout the development process, because he wanted the chance to "be creative," and had that "opportunity" with Voices UP! "We [made] up the story," said one participant, referring to a collective means of creative expression present in Voices UP!

Another participant, who chose her puppet as the object representing her experience of Voices UP! (see Figure 2), emphasized the "feelings" and "memories" present in the puppet she created. As suggested in Excerpt 2: A Puppet Is Born, the participant named her puppet in a way that was personally significant to her. The participant explained that the puppet gave her the opportunity to express her "ideas" to the audience.

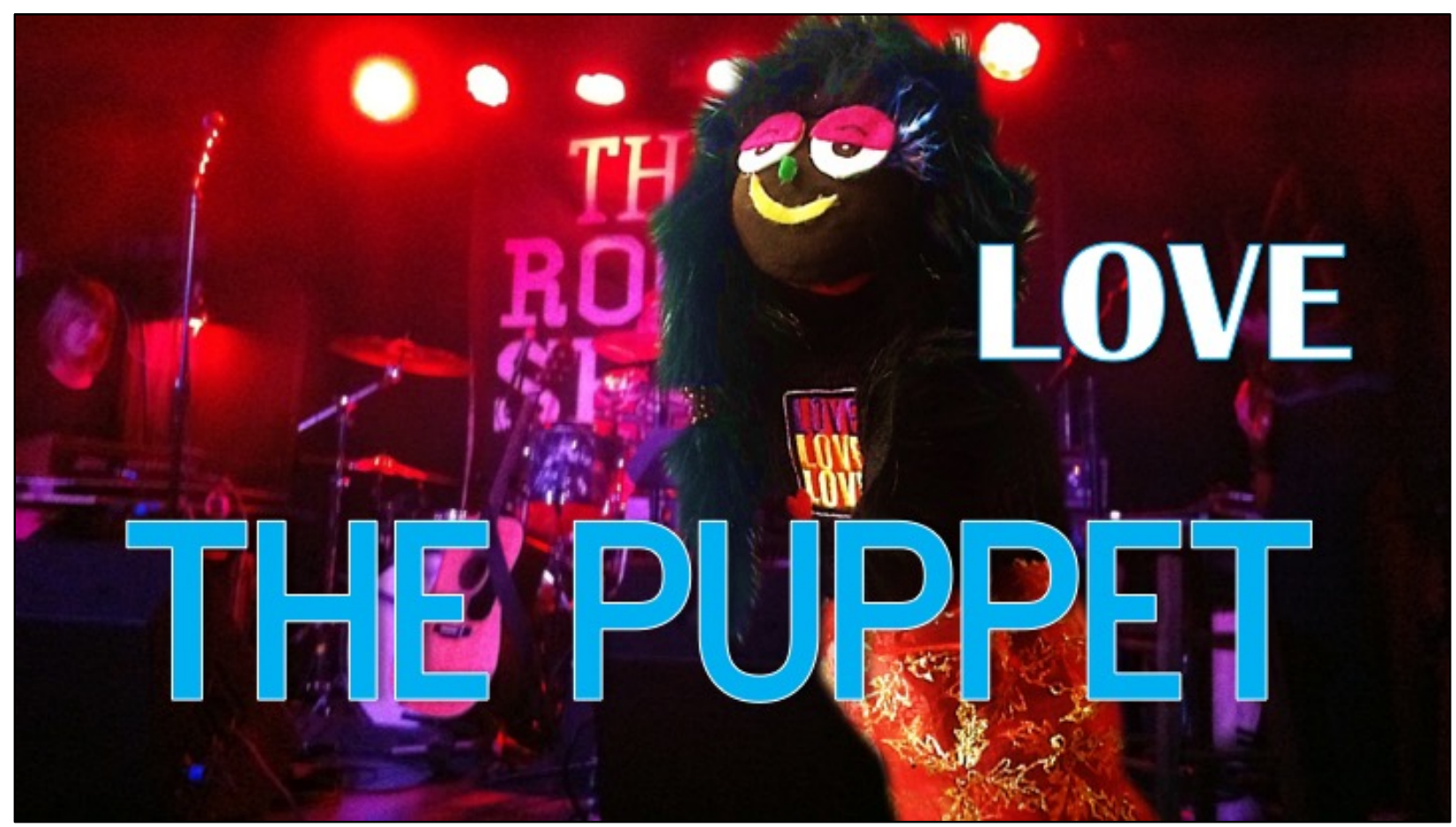

Fig. 2: Chosen Object. "Love". Puppet by Teresa Shu-Tak Wong. Photo design credit: Voices UP! Collective. 


\section{Dramatizing Data}

Plays within plays, as well as plays and scenes about playmaking and performance, have been rich sites of exploration for both historical and contemporary playwrights, from Shakespeare to Stoppard. Give Me Your Hands attempts to represent and lift all data sources, including interview transcripts, sketches, and objects chosen by participants. As such, the script becomes more than just direct quotes from interviews; instead, it's an artistic rendering. The narratives generated from data are transformed into stories of three fictional characters, highlighting the essence of the community members' experiences. This play is only one possibility for dramatizing the data collected for this study-while offering an in-depth exploration of the participants' experiences, it attempts to refrain from suggesting the collected data can lead to a single, specific understanding (Sinclair, 2014). The play presents the data in a form to be experienced, rather than only examined.

In Give Me Your Hands, the puppets address the audience directly throughout the piece. Audience-performer interactions serve to further highlight the centrality of relationships to the participants' experience of collective playmaking. At various points the performers, through the puppets, relate to the audience as confidants, participants in a sock-making workshop, and an actual crowd gathered to watch a show.

Butler-Kisber (2005) states that, "borders are crossed" in arts-based research, and "deeper and varied understandings occur" (p. 215). The character of Ehren in Give Me Your Hand disrupts the traditional researcher role as distant observer, removed from the analysis. Ehren, like Chris in the actual research, was in the middle of the creative process, generating and facilitating the research. Therefore, his reflexive and reflective voice via the puppet Ehren becomes critical in understanding the dynamics at play in this inquiry process.

\section{Give Me Your Hands Excerpt 5: So Many Questions}

EHREN After the show, we have a talk-backa question period with the cast onstage.

The performers sit in unison.

EHREN Someone puts up their hand, and I point to them-

ZHAN (hand up) "Are you doing any work evaluating this experience for people?

Like-what was it like for you to make a play together?

What are you all taking from it?"

EHREN One of the cast says-

SHELLEY "Actually, that's what Ehren's research is on."

EHREN "Yeah, I'm making a play about making a play."

$\mathrm{I}$ 'm wondering if my cheeks are as red as they feel. 
How am I going to translate this experience into research?

ZHAN

(to EHREN) Can we help?

I think English has this saying too, right?

"Two heads are better than one."

We can do things successfully, even though we are not experienced,

if we do it together.

That's what the puppets stand for, to me-

Our strong group.

Because if you are by yourself, you can't do those things.

That's a group of people, making good things, all together.

SHELLEY I would never have this opportunity if

I was just by myself within the four walls.

(Repeats quietly) Within the four walls.

Everybody grows old.

But people grow old with grace.

Regardless from the teen to the twenties

to the thirties to the forties whatever-

you've got to keep going, keep learning.

ZHAN You help yourself by helping others.

Working on this project,

You pick things from other people.

SHELLEY It's not only the making of the puppets, or even the writing. For weeks, downstairs in the parkade, we were setting up the set, and we were sawing and then nailing and painting.

ZHAN You don't use a pen or ink?

Just use different instruments-

the hammer, the nails.

You're still a part of the group.

You need different people to do different things,

You need everybody.

SHELLEY It's really amazing.

I mean, I can pick up chopsticks, forks and knives,

but not a saw!

And I did. I sawed a piece of the set!

It's part of a very important memory in my life.

ZHAN Also, you know, Ehren-you are a very good leader.

EHREN (to ZHAN) But like Shelley,

I learned how to saw

when we made the set.

I wasn't leading any of that.

I never would have built a set on my own. 
And you taught me how to drill, Zhan!

I like what you said before,

"Leading-Group Members."

Everybody's leading, everyone

took the lead in the project.

ZHAN (to EHREN) Yes, a good leader, leads good group members.

It takes both.

EHREN Thanks, Zhan.

ZHAN You don't have to thank me.

After Voices UP!, we're more than just friends, we're like brother and sister.

\section{Discussion}

Voices UP!, a collaborative play creation project, was an arts-based learning opportunity for interested community members in the DTES. The stories participants shared in this study-relationship building, of gaining transferable skills, and exploring their own artistry-expand our conception of collective theatre and art creation to include therapeutic potential. This study reflects recent research on the mental health benefits of social connectedness and group membership involving seniors and diverse cultural identities in Canada (Puyat, 2013; Richmond, Ross, \& Egeland, 2007), as well as research suggesting art creation may support social relationships among seniors (Balyasnikova, Higgins, \& Hume, 2017; Bennington, Backos, Harrison, Etherington Reader, \& Carolan, 2016). If collective theatre creation is a potentially therapeutic endeavor, our responsibilities as educators and researchers change, particularly when working with participants in marginalized communities. Chris needed to consider balancing multiple roles, as an artist, researcher, educator, and a facilitator of a therapeutic experience.

This study represents an example of how collective playmaking and research based-theatre can be utilized by researchers as a means of capturing experiences that may be difficult to present fully in traditional academic writing. Research-based theatre is a methodology (Belliveau \& Lea, 2016) that attempts to bridge an embodied art form with scholarly writing, exploring the space between art and inquiry. Collective theatre creation disrupts the traditional hierarchy of researcher-participant and/or teacher-student, to facilitate a sharing of leadership roles, as the collective explores individual and group narratives together. Offering this action-based, collaborative storytelling program to the DTES community, inside rehearsal halls and performance spaces, supports the efforts of educators and practitioners to make relevant learning experiences that contribute to well-being accessible to a greater number of community members in diverse contexts. The research presented here also suggests that community members can be co-creators of an experience that is creatively fulfilling and therapeutic. Co-creation means collective art-making can be adapted to whoever is in the room-acknowledging and embracing diverse identities and backgrounds, drawing on the group's strengths, and encouraging shared growth. 


\section{Limitations}

This research project was conducted in a specific community and organization. It involved DTES individuals who were interested in creating and performing a play. Therefore, the insights and findings are not generalizable. The data and narratives presented here are not meant to be reflective of all patrons of the Learning Exchange, or all community members of the DTES. As each theatrical process is unique, a different organization engaging in collective creation may generate different experiences than those presented here.

\section{Implications for Further Research}

Following on the description and advice of the participants who stated that evaluation should be left to the audience, future studies could also examine the impact on audience members who witness collectively created performances by community members (Belliveau \& Nichols, 2017). Another line of inquiry could explore the benefits participants report from taking part in collective creation projects of shorter durations, for example, for several days or several weeks.

\section{A Concluding Dialogue}

\section{Give Me Your Hands Excerpt 6: Remember What Puck Said?}

ZHAN Even though now we have finished, I still look at the photo of the cast and think, "Oh what a good time!" Sometimes I meet Shelley outside too, then we stop, and yap yap yap for a few minutes then-bye-bye.

Not only here we become almost a family, outside we are friends too.

SHELLEY I consider this play as one of my masterpieces. Through the project I have done it the best that I can. Maybe I screwed up a little bit here and thereI forgot a word-but that's alright, I did my part. You remember what Puck said, at the at the end? "If you don't like it, it's okay. But I am honest to myself." Okay? "Give me your hands. You give me your hand." 


\section{Note}

1. All community members who took part in Voices UP! from July-August of 2017, during the data collection phase of this study, were invited to participate. The four who agreed had the option of being credited by name or a chosen alias in study results and artwork. This research received ethical approval from the Behavioral Research Ethics Board at the University of British Columbia, certificate number H17-00101.

\section{Acknowledgments}

We wish to thank the community members involved in Voices UP!, as well as the UBC Learning Exchange and its staff. Give Me Your Hands was collectively written by Christopher Cook, Jay, Ken Lee, Eagle Sky, and Teresa Shu-Tak Wong. This research was conducted on the traditional, unceded territory of the Musqueam, Squamish, and Tsleil-Waututh Nations.

\section{References}

Aristotle. (1970). Poetics. (G. F. Else, Trans.). Ann Arbor, MI: University of Michigan Press.

Balyasnikova, N., Higgins, S., \& Hume, M. (2017). Enhancing teaching English as an additional language through playfulness: Seniors (Ethno)Drama Club in Vancouver's Downtown Eastside. TESOL Journal. Retrieved from https://doi.org/10.1002/tesj.337

Belliveau, G. (2007). Dramatizing the data: An ethnodramatic exploration of a playbuilding process. Arts \& Learning Research Journal, 23(1), 31-51.

Belliveau, G., \& Lea, G. W. (Eds.). (2016). Research-based theatre: An artistic methodology. Bristol, UK: Intellect.

Belliveau, G., \& Nichols, J. (2017). Audience responses to Contact!Unload: A Canadian research-based play about returning military veterans. Cogent Arts \& Humanities, 4(1), 1351704. Retrieved from https://doi.org/10.1080/23311983.2017.1351704

Bennington, R., Backos, A., Harrison, J., Etherington Reader, A., \& Carolan, R. (2016). Art therapy in art museums: Promoting social connectedness and psychological well-being of older adults. The Arts in Psychotherapy, 49, 34-43. Retrieved from https://doi.org/10.1016/j.aip.2016.05.013

Boydell, K. M., Hodgins, M., Gladstone, B. M., Stasiulis, E., Belliveau, G., Cheu, H., et al. (2016). Arts-based health research and academic legitimacy: Transcending hegemonic conventions. Qualitative Research, 16(6), 681-700. Retrieved from https://doi.org/10.1177/1468794116630040

Braun, V., \& Clarke, V. (2006). Using thematic analysis in psychology. Qualitative Research in Psychology, 3(2), 77-101. Retrieved from https://doi.org/10.1191/1478088706qp063oa

Butler-Kisber, L. (2005). The potential of artful analysis and portrayals in qualitative inquiry. Counterpoints, 275, 203-217. Retrieved from http://www.jstor.org/stable/42978786 
City of Vancouver. (2014). Downtown Eastside Plan (Local Area Plan). Vancouver, BC: City of Vancouver. Retrieved from http://vancouver.ca/files/cov/downtown-eastside-plan.pdf

Cox, S. M., Brett-MacLean, P., \& Courneya, C. A. (2016). "My turbinado sugar": Art-making, well-being and professional identity in medical education. Arts \& Health, 8(1), 65-81. Retrieved from https://doi.org/10.1080/17533015.2015.1037318

Gildin, M., Binder, R., Chipkin, I., Fogelman, V., Goldstein, B., \& Lippel, A. (2013). Learning by heart: Intergenerational theater arts. Harvard Educational Review, 83(1), 150-152. Retrieved from https://doi.org/10.17763/haer.83.1.r16186gr82t78471

Leavy, P. (2009). Method meets art: Arts-based research practice. New York, NY: Guilford Press.

Leckey, J. (2011). The therapeutic effectiveness of creative activities on mental well-being: A systematic review of the literature. Journal of Psychiatric and Mental Health Nursing, 18(6), 501-509. Retrieved from https://doi.org/10.1111/j.1365-2850.2011.01693.x

Lomas, T. (2016). Positive art: Artistic expression and appreciation as an exemplary vehicle for flourishing. Review of General Psychology, 20(2), 171-182. Retrieved from https://doi.org/10.1037/gpr0000073

Mackenzie, D., \& Belliveau, G. (2011). The playwright in research-based theatre: Exploring the role of the playwright. Canadian Journal of Practice-Based Research in Theatre, 3(1), 1-23. Retrieved from http://cjprt.uwinnipeg.ca/index.php/cjprt/article/view/30/19

Mitchell, C., \& Ezcurra, M. (2017). Picturing (as) resistance: Studying resistance and well-being of Indigenous girls and young women in addressing sexual violence. LEARNing Landscapes, 10(2), 207224. Retrieved from http://ojs.learnquebec.ca/index.php/learnland/article/view/Picturing\%20\%28as\%29-Resistance-Studying-Resistance-and-Well-Being-of-Indigenous-Girls-and-Young-Womenin-Addressing-Sexual-Violence

O'Connor, P., \& O'Toole, J. (2017). Editorial. Applied Theatre Research, 5(2), 63-65. Retrieved from https://doi.org/10.1386/atr.5.2.63_2

Prendergast, M., \& Belliveau, G. (2018). Misperformance ethnography. In M. Cahnmann-Taylor \& R. Siegesmund (Eds.), Arts-based research in education: Foundations for practice (pp. 99-114). New York, NY: Routledge.

Puyat, J. H. (2013). Is the influence of social support on mental health the same for immigrants and nonimmigrants? Journal of Immigrant and Minority Health, 15(3), 598-605. Retrieved from https://doi.org/10.1007/s10903-012-9658-7

Richmond, C. A. M., Ross, N. A., \& Egeland, G. M. (2007). Social support and thriving health: A new approach to understanding the health of Indigenous Canadians. American Journal of Public Health, 97(10), 1827-1833. Retrieved from https://doi.org/10.2105/AJPH.2006.096917

Sadeghi-Yekta, K. (2017). In the Limelight: Enthusiasm, commitment and need. Research in Drama Education: The Journal of Applied Theatre and Performance, 22(1), 144-147. Retrieved from https://doi.org/10.1080/13569783.2016.1262253

Sinclair, C. (2014). We are not alone: The quest for dialogic spaces as sites of inquiry. Journal of Artistic and Creative Education, 8(1), 48-77. Retrieved from http://jaceonline.com.au/issues/volume-8-number-1/ 
Snow, S., D'Amico, M., \& Tanguay, D. (2003). Therapeutic theatre and well-being. The Arts in Psychotherapy, 30(2), 73-82. Retrieved from https://doi.org/10.1016/S0197-4556(03)00026-1

Stuckey, H. L., \& Nobel, J. (2010). The connection between art, healing, and public health: A review of current literature. American Journal of Public Health, 100(2), 254-263. Retrieved from https://doi.org/10.2105/AJPH.2008.156497

Wager, A. C. (2014). Applied drama as engaging pedagogy: Critical multimodal literacies with street youth (PhD Thesis). University of British Columbia. Retrieved from https://open.library.ubc.ca/cIRcle/collections/24/items/1.0166999

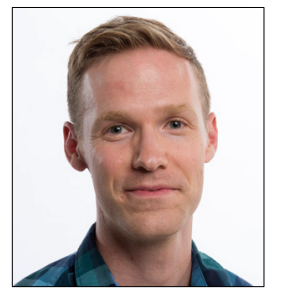

Christopher Cook recently completed his MA in counselling psychology at the University of British Columbia. With a background as an actor and a playwright, Chris is passionate about theatre as a therapeutic, learning, and research tool. His playwriting credits include The Better Parts of Mourning (the frank theatre company), Strip (Staircase Theatre), Gerty: Live! In Concert! (BC Buds Festival), and Quick Bright Things (Persephone Theatre). Voices UP! and Give Me Your Hands offered Chris his first experiences of collective creations.

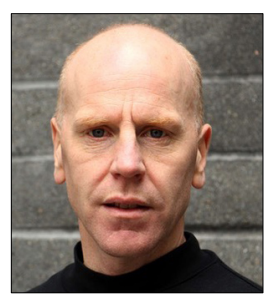

George Belliveau is Professor of Theatre/Drama Education at the University of British Columbia, Canada. His research interests include research-based theatre, drama and social justice, drama and L2 learning, drama across the curriculum, drama and health research, and Canadian theatre. His scholarly and creative writing can be found in various arts-based and theatre education journals, along with chapters in edited books. He has written or edited six books, including a coedited one with Graham Lea, Research-Based Theatre: An Artistic Methodology (Intellect, 2016). 